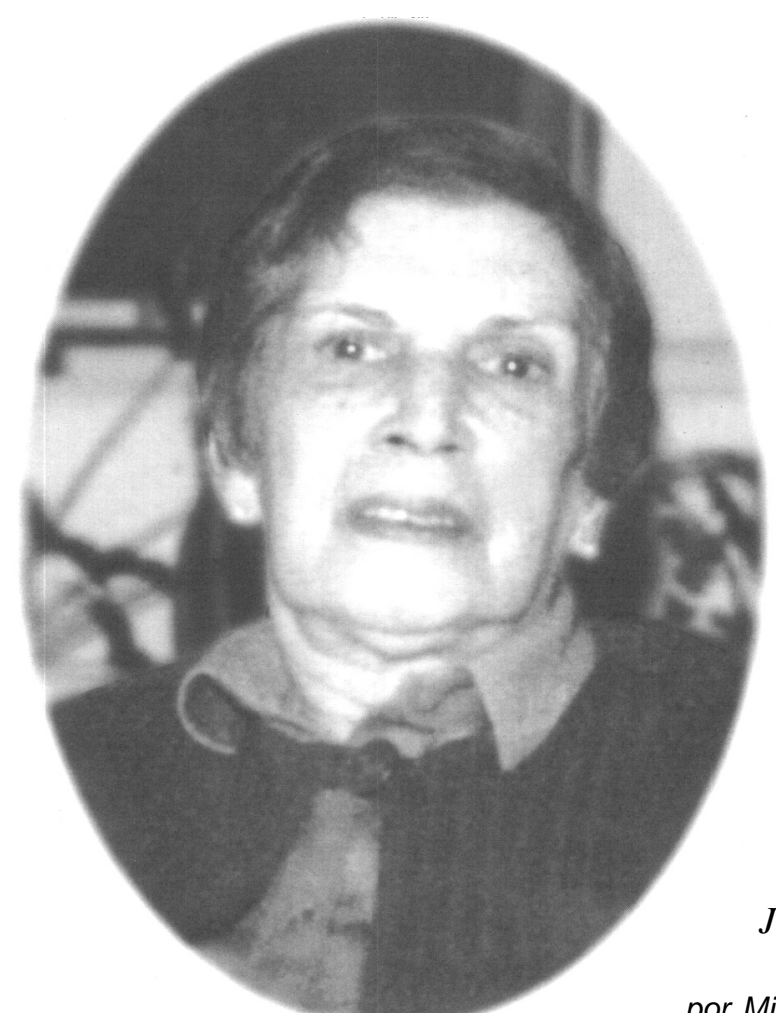

\title{
Elisa Dias Veloso
}

Nascida em Minas Cerais, em 16 de fevereiro de 1914, Elisa Dias Veloso iniciou e consolidou sua formação psicológica sob a orientação de dois grandes mestres: Helena Antipoff, no Laboratório de Psicologia da Escola de Aperfeiçoamento de Minas Gerias (1936-1941), e Emílio Mira y López, de quem foi aluna no memorável "Curso do DASP', sobre Seleção, Orientação e Readaptação Profissional, no Rio de Janeiro (1945-1948).

Em 1948, voltaria a seguir curso ministrado por Mira y López, desta vez no ISOP, sobre Psicoterapia

Menor. Em busca de intercâmbio e treinamento avançado, fez estágios em clínicas da Grã-Bretanha (1952) e dos Estados Unidos (1965-1966) e participou de Seminário sobre Saúde Mental Infantil, em Montevidéu (1955), na condição de bolsista da ONU, da Comissão Fulbright e do Conselho Britânico.

Viveu a psicologia como docente, orientadora e terapeuta de crianças e de adolescentes. Professora, lecionou no Instituto de educação de Belo Horizonte (1938-1941), na pós-graduação médica da Escola Nacional de Saúde Pública (1960-1964) e nos cursos de graduação (1960-1966) e pós graduação em psicologia (1967-1969) da PUC-RJ.

Desempenhou as atribuições de orientadora e terapeuta em consultório (1953-em torno de 1985) e como técnica em educação, cargo conquistado por concurso. De início, atuou no INEP (1941-1944). Posteriormente, no Departamento Nacional da Criança (1944-1969). Suas maiores contribuições estiveram associadas ao Centro de Orientação Juvenil, COJ, instalado no âmbito do Departamento Nacional da Criança, ao qual se dedicou de 1945 a 1968, chefiando-o de 7960 a 7964.

Sempre atuante e comprometida profissionalmente, foi membro da Associação Brasileira de Psicologia Aplicada, da Sociedade Interamericanas de Psicologia, da Associação Internacional de Psicologia Aplicada, do International Council of Psychologists, da Comissão Interministerial para elaboração do anteprojeto de lei que criou os Conselhos de Psicologia. Integrou os plenários do CRP-05 (1974-1976) e do CFP (1976-1979), onde presidiu a Comissão de Ética.

Elisa Dias Veloso publicou cerca de 50 artigos, realizou estudos e pesquisas, participou de congressos e seminários, ministrou cursos e conferências em diversos estados do Brasil. Em 1982, foi agraciada com o Prêmio Dante Moreira Leite, instituído naquele ano pelo Conselho Federal de Psicologia.

"Dona Elisa", como é carinhosamente chamada, foi homenageada no Seminário Anual Interdisciplinar da Associação Brasileira de Psicologia Aplicada, no dia 30 de outubro deste ano, no auditório da Fundação Getúlio Vargas, Rio de Janeiro. 